\title{
PENGARUH SUHU DAN LAMA PENYIMPANAN TERHADAP KANDUNGAN VITAMIN A DAN VITAMIN C BUAH GANDARIA (Bouea macrophylla Griff) SERTA IMPLIKASINYA PADA PEMBELAJARAN BIOLOGI
}

\author{
Agnes A. Patty', P.M. Papilaya' ${ }^{2}$, P.M.J. Tuapattinaya ${ }^{2}$ \\ ${ }^{1}$ Alumni Program Studi Pendidikan Biologi \\ ${ }^{2}$ Staf Pengajar Program Studi Pendidikan Biologi
}

E-mail: patty_agnes@yahoo.com

\begin{abstract}
Background: The purpose of this study was to determine whether there is influence of temperature and storage time to vitamin A and vitamin C content in gandaria.

Method: This study was an experimental study using Completely Randomized Design (RAL), with a combination of cold and room temperature treatments and storage duration (1, 4, 7, and 10 days). Each treatment was repeated three times. The parameters observed were vitamin $A$ and vitamin $C$ content of gandaria. Analysis of vitamin A and C content using UV-Vis Spectrophotometric method. The data obtained were analyzed with ANOVA and continued with Duncan Test.

Results: The results showed that temperature and storage time had an effect on vitamin $A$ and vitamin C content of gandaria. The highest decrease in vitamin A content was found in storage at room temperature for 10 days that was $21.69 \%$, while in cold temperature only $15.36 \%$. The content of vitamin $\mathrm{C}$ in gandaria stored at room temperature for 10 days decreased $35.05 \%$, while in cold temperature only $21.03 \%$.

Conclusion: The longer the storage and the high temperature, the levels of vitamin A and vitamin C decreases.
\end{abstract}

Keywords: Gandaria, vitamin A, vitamin C, spectrophotometry

\begin{abstract}
Abstrak
Latar Belakang: Tujuan dari penelitian ini adalah untuk mengetahui ada tidaknya pengaruh suhu dan lama penyimpanan terhadap kandungan vitamin $\mathrm{A}$ dan vitamin $\mathrm{C}$ pada buah gandaria.

Metode: Penelitian ini adalah penelitian eksperimental dengan menggunakan Rancangan Acak Lengkap (RAL), dengan kombinasi perlakuan suhu dingin dan suhu kamar serta perlakuan lama penyimpanan (1, 4, 7, dan 10 hari). Masing-masing perlakuan diulang sebanyak tiga kali. Parameter yang diamati adalah kandungan vitamin $A$ dan vitamin $C$ buah gandaria. Analisis kandungan vitamin $A$ dan C menggunakan metode Spektrofotometri UV-Vis. Data yang diperoleh dianalisis dengan ANOVA dan dilanjutkan dengan Uji Duncan.

Hasil: Hasil penelitian menunjukkan bahwa suhu dan lama penyimpanan berpengaruh terhadap kandungan vitamin $\mathrm{A}$ dan vitamin $\mathrm{C}$ buah gandaria. Penurunan kandungan vitamin $\mathrm{A}$ tertinggi terdapat pada penyimpanan pada suhu kamar selama 10 hari yaitu $21,69 \%$, sedangkan pada suhu dingin hanya $15,36 \%$. Kandungan vitamin C pada buah gandaria yang disimpan pada suhu kamar selama 10 hari mengalami penurunan $35,05 \%$, sedangkan pada suhu dingin hanya $21,03 \%$.

Kesimpulan: Semakin lama penyimpanan dan tinggi suhu, maka kadar vitamin A dan vitamin C semakin menurun.
\end{abstract}

Kata kunci: Gandaria, vitamin A, vitamin C, spektrofotometri 


\section{PENDAHULUAN}

Masalah gizi bukan hanya merupakan masalah nasional tetapi juga internasional. Perencanaan untuk meningkatkan pengadaan pangan bagi masyarakat sangat penting, baik untuk pembangunan nasional maupun untuk kesejahteraan manusia. Sehubungan dengan hal tersebut di atas maka peningkatan keadaan pangan dan gizi perlu mendapat perhatian terutama dalam penyimpanannya, karena dalam pangan terkandung zat-zat gizi yang sifatnya kurang stabil antara lain adalah vitamin A dan vitamin C.

Vitamin A merupakan vitamin yang larut dalam lemak dan berguna untuk pemeliharaan kesehatan dan kelangsungan hidup. Vitamin A berfungsi dalam hal penglihatan, pertumbuhan dan perkembangan, pencegahan kanker dan penyakit jantung. Vitamin A yang terkandung dalam suatu bahan makanan tidak bisa diujikan, sehingga pada umumnya dalam sebuah penelitian yang diteliti adalah provitamin A yaitu $\beta$-karoten (Almatsier dalam Azeliya, 2013). Vitamin A mudah rusak oleh karena kenaikan suhu dan sinar di sekelilingnya. Semakin tinggi suhu, semakin besar penurunan kandungan vitamin A oleh karena terdegradasi oleh panas dan kenaikan suhu (Hook, 2007).

Vitamin $\mathrm{C}$ disebut juga asam askorbat, merupakan vitamin yang paling sederhana, mudah berubah akibat oksidasi, tetapi amat berguna bagi manusia. Struktur kimianya terdiri dari rantai 6 atom $\mathrm{C}$ dan kedudukannya tidak stabil $\left(\mathrm{C}_{6} \mathrm{H}_{8} \mathrm{O}_{6}\right)$, karena mudah bereaksi dengan $\mathrm{O}_{2}$ di udara menjadi asam dehidroaskorbat. Vitamin ini merupakan fresh food vitamin karena sumber utamanya adalah buah-buahan dan sayuran segar. Vitamin C bersifat menangkal radikal bebas dan dapat menurunkan laju mutasi dalam tubuh sehingga resiko berbagai penyakit degeneratif dapat diturunkan. Vitamin C mudah teroksidasi jika terkena udara dan proses ini dipercepat oleh panas dan sinar (Martin et al. dalam Masfufatun, dkk, 2009).

Salah satu bahan makanan yang mengandung vitamin $\mathrm{A}$ dan $\mathrm{C}$ adalah buah gandaria. Gandaria adalah satu tumbuhan asli Indonesia yang termasuk dalam kelompok suku Anacardiaceae. Di Indonesia gandaria memiliki daerah penyebaran yang sempit, yakni di Pulau Sumatera, sebagian Jawa, Maluku, Kalimantan dan Papua. Di Maluku sendiri, produksi buah gandaria belum terdata secara akurat, sehingga ada kemungkinan buah lokal ini dapat punah kalau tidak segera dilestarikan. Umumnya buah gandaria oleh wisatawan yang berkunjung ke Maluku dijadikan sebagai oleh-oleh. Oleh-oleh buah gandaria segar yang biasanya dibawa oleh wisatawan ke luar negeri atau ke daerah lain di Indonesia kadangkala mengalami kerusakan selama dalam perjalanan. Hal ini disebabkan sifat buah segar yang mudah rusak (Mailoa, 2012).

Untuk mengatasi masalah tersebut maka buah gandaria perlu diberikan perlakuan agar dapat memperpanjang umur simpan sekaligus mempertahankan kandungan gizi buah gandaria. Penggunaan suhu rendah merupakan cara yang efektif untuk memperpanjang daya simpan bahan segar (Bakhtiar, 2008). Berdasarkan hasil penelitian Masfufatun (2010), kadar vitamin $\mathrm{C}$ dalam jambu biji yang disimpan pada suhu kamar selama 10 hari mengalami penurunan 46 , 35\% dan 39\% pada suhu dingin. Penelitian tentang $\beta$-karoten dan Vitamin C dilakukan oleh Tungriani pada tahun 2012 yang dijuikan pada berbagai varietas talas berdasarkan suhu dan lama penyimpanan, bahwa kadar $\beta$-karoten dan vitamin $\mathrm{C}$ yang diperoleh pada penyimpanan talas selama satu minggu dan satu bulan mengalami penurunan.

Penelitian tentang pengaruh suhu dan lama penyimpanan telah banyak dilakukan terhadap berbagai macam buah maupun sayuran. Namun, penelitian tentang suhu dan lama penyimpanan untuk buah gandaria belum pernah dilakukan sehingga penulis tertarik untuk melakukan penelitian tersebut pada buah gandaria.

Berdasarkan latar belakang tersebut, penulis ingin untuk melakukan suatu penelitian tentang "Pengaruh suhu dan lama penyimpanan terhadap kandungan vitamin $\mathrm{A}$ dan vitamin C pada Buah Gandaria (Bouea macrophylla Griff)."

Tujuan dari penelitian ini adalah untuk mengetahui ada tidaknya pengaruh suhu dan lama penyimpanan terhadap kandungan vitamin A dan vitamin C pada buah gandaria. 


\section{METODE PENELITIAN Alat dan Bahan}

Alat-alat yang digunakan adalah pisau, blender, spektrofotometer, Colom Kromatografi, timbangan analitik erlnmeyer, pengaduk tabung reaksi, labu takar, pompa vakum, hotplate, shaker, kertas saring. Thermometer, dan kamera.

Bahan-bahan yang digunakan adalah daging buah gandaria, asam askorbat, aquades, $\mathrm{n}$ - hexane, aceton, magnesium karbonat, natrium sulfat, dan aluminium oxide.

\section{Rancangan Percobaan}

Percobaan menggunakan Rancangan Acak Lengkap dengan kombinasi dua perlakuan suhu yaitu, suhu dingin $\left(12^{0}-16^{\circ} \mathrm{C}\right)$ dan suhu kamar $\left(28^{\circ}-32^{\circ} \mathrm{C}\right)$ serta lama penyimpanan 0 hari sebagai kontrol, 1 hari, 4 hari, 7 hari, dan 10 hari dan diulang tiga kali. Data yang diperoleh dianalisis dengan Anova dan bila ada pengaruh perlakuan yang signifikan, maka dilanjutkan dengan uji Duncan.

\section{Pelaksanaan Penelitian}

Pengambilan sampel dilakukan dengan metode puposif sampling. Sebagai kelompok pembanding tidak dilakukan penyimpanan. Sedangkan pada kelompok perlakuan, sebelum ditentukan kandungan vitamin $A$ dan $C$, dilakukan penyimpanan dengan variabel suhu dan lama penyimpanan yaitu suhu dingin $\left(12^{\circ}-16^{\circ} \mathrm{C}\right)$ dan suhu kamar $\left(28^{\circ}-32^{\circ} \mathrm{C}\right)$ dengan lama penyimpanan $1,4,7$, dan 10 hari. Vitamin $\mathrm{A}$ dan $C$ dianalisis dengan menggunakan Spektrofotometer.

\section{Parameter Pengujian \\ Uji Vitamin C dengan Metode Spektrofotometer (Selimovic dalam Tungriani, $d k k, 2012)$ \\ Buah gandaria dicuci dan dihaluskan, kemudian ditimbang 5-10 g. Masukkan dalam erlenmeyer dan tambahkan aquades}

secukupnya, kemudian diaduk dan disaring dengan menggunakan kertas saring. Hasil penyaringan dimasukkan ke dalam labu takar dan tambahkan aquades. Selanjutnya, pembuatan larutan standar vitamin $C$ dan ukur absorbansi dari larutan standar vitamin $C$ dan sampel pada panjang gelombang 262 $\mathrm{nm}$. Kemudian tentukan konsentrasi sampel berdasarkan kurva standar yang telah dibuat.

\section{Uji Vitamin A dengan Metode \\ Spektrofotometer (Parwata, dkk, 2010)}

Buah gandaria dicuci dan dihaluskan, kemudian ditimbang 5-10 g. Masukkan ke dalam erlenmyer dan tambahkan magnesium karbonat dan $100 \mathrm{ml}$ larutan aceton: n-hexane. Larutan diaduk dan disaring dengan kertas saring. Pindahkan hasil penyaringan ke dalam corong pisah dan lakukan pemisahan polar dan nonpolar. Masukkan lapisan nonpolar ke dalam corong pisah dan lakukan ekstraksi dengan $15 \mathrm{ml}$ larutan n-hexane. Gabungkan lapisan nhexane dengan hasil pemisahan. Siapkan kolom kromatografi dengan fase diam aluminium oxide dan fase gerak yang terdiri dari $n$ - hexane dan aceton. Campurkan fase gerak dengan fase diam, tambahkan natrium sulfat di atas fase diam. Jalankan fase gerak sampai larutan yang tertinggal kira-kira $1 \mathrm{~cm}$ di atas lapisan natrium sulfat. Tampung hasil pemisahan yang telah melewai kolom kromatografi. Siapkan larutan standar vitamin A dan ukur nilai absorbansi larutan standar vitamin A dengan spektrofotometer pada panjang gelombang $450 \mathrm{~nm}$.

\section{HASIL DAN PEMBAHASAN \\ Hasil \\ Vitamin A}

Rata-rata kandungan vitamin A pada buah gandaria sesudah perlakuan suhu dan lama penyimpanan dapat dilihat pada Gambar 1 di bawah ini. 


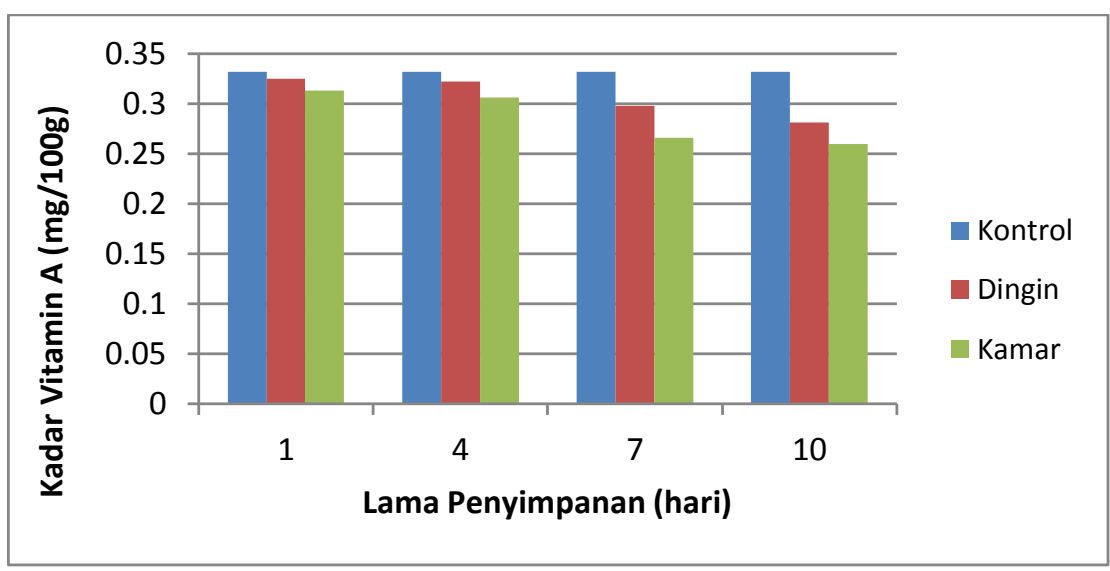

\section{Gambar 1. Pengaruh Suhu dan Lama Penyimpanan Terhadap Kandungan Vitamin A Buah Gandaria}

Kandungan vitamin A tertinggi terdapat pada kontrol (tanpa penyimpanan) yaitu sebesar 0,332 $\mathrm{mg} / 100 \mathrm{~g}$ dan ketika disimpan pada suhu dingin dengan lama penyimpanan 1 hari, kandungan vitamin $A$ mengalami penurunan menjadi 0,325 $\mathrm{mg} / 100$ g. Selanjutnya pada lama penyimpanan 4 hari, 7 hari, dan 10 hari yang disimpan pada suhu dingin, mengalami penurunan berturut-turut menjadi 0,322 $\mathrm{mg} / 100 \mathrm{~g}, \quad 0,298 \mathrm{mg} / 100 \mathrm{~g}$, dan 0,281 $\mathrm{mg} / 100 \mathrm{~g}$. Penyimpanan pada suhu kamar selama 1 hari terjadi penurunan kandungan vitamin A dibandingkan dengan kontrol (tanpa penyimpanan) menjadi 0,313 $\mathrm{mg} / 100 \mathrm{~g}$, dan pada lama penyimpanan 4 hari, 7 hari dan 10 hari terjadi penurunan berturut-turut menjadi $0,306 \mathrm{mg} / 100 \mathrm{~g}, 0,266$ $\mathrm{mg} / 100 \mathrm{~g}$, dan $0,260 \mathrm{mg} / 100 \mathrm{~g}$. Penurunan kandungan vitamin A tertinggi terdapat pada penyimpanan suhu kamar selama 10 hari yaitu $21,69 \%$, sedangkan pada suhu dingin hanya $15,36 \%$.

Hasil uji Anova dari vitamin A menunjukkan bahwa suhu dan lama penyimpanan sangat berpengaruh terhadap kandungan vitamin A buah gandaria, sedangkan interaksi kedua perlakuan tersebut tidak berpengaruh nyata terhadap kandungan vitamin A buah gandaria, kemudian dilanjutkan dengan uji Duncan. Hasil Uji Duncan suhu dan lama penyimpanan terhadap kandungan vitamin $\mathrm{A}$ gandaria dapat dilihat pada Tabel 1 di bawah ini.

Tabel 1. Hasil Uji Duncan Suhu dan Lama Penyimpanan Terhadap Kandungan Vitamin A Buah Gandaria

\begin{tabular}{ccc}
\hline Suhu $\left({ }^{\circ} \mathrm{C}\right)$ & Rerata & Notasi \\
\hline Dingin $\left(12-16^{\circ} \mathrm{C}\right)$ & $0,286^{\mathrm{a}}$ & $\mathrm{a}$ \\
Kamar $\left(28-32^{\circ} \mathrm{C}\right)$ & 0,312 & $\mathrm{~b}$ \\
\hline & & \multicolumn{2}{c}{ Notasi } \\
\hline Lama Penyimpanan & Rerata & $\mathrm{a}$ \\
(hari) & 0.2705 & $\mathrm{a}$ \\
\hline 10 & 0.2818 & \multicolumn{2}{c}{$\mathrm{b}$} \\
4 & 0.3140 & $\mathrm{~b}$ \\
1 & 0,3188 & $\mathrm{~b}$
\end{tabular}

Keterangan: Angka-angka yang diikuti oleh notasi yang sama tidak menunjukkan perbedaan yang nyata. 
Hasil uji Duncan Vitamin A buah gandaria untuk perlakuan suhu menunjukkan bahwa perlakuan penyimpanan pada suhu dingin berbeda nyata dengan perlakuan penyimpanan pada suhu kamar. Hasil uji Duncan Vitamin A buah gandaria untuk perlakuan lama penyimpanan menunjukkan bahwa kontrol (tanpa penyimpanan) tidak berbeda nyata dengan penyimpanan selama 1 hari dan 4 hari tetapi berbeda nyata dengan penyimpanan pada 7 hari dan 10 hari. Sedangkan lama penyimpanan 7 hari tidak berbeda nyata dengan penyimpanan selama 10 hari.

\section{Vitamin C}

Rata-rata kandungan Vitamin C pada buah gandaria sesudah perlakuan suhu dan lama penyimpanan dapat dilihat pada Gambar 2 di bawah ini.

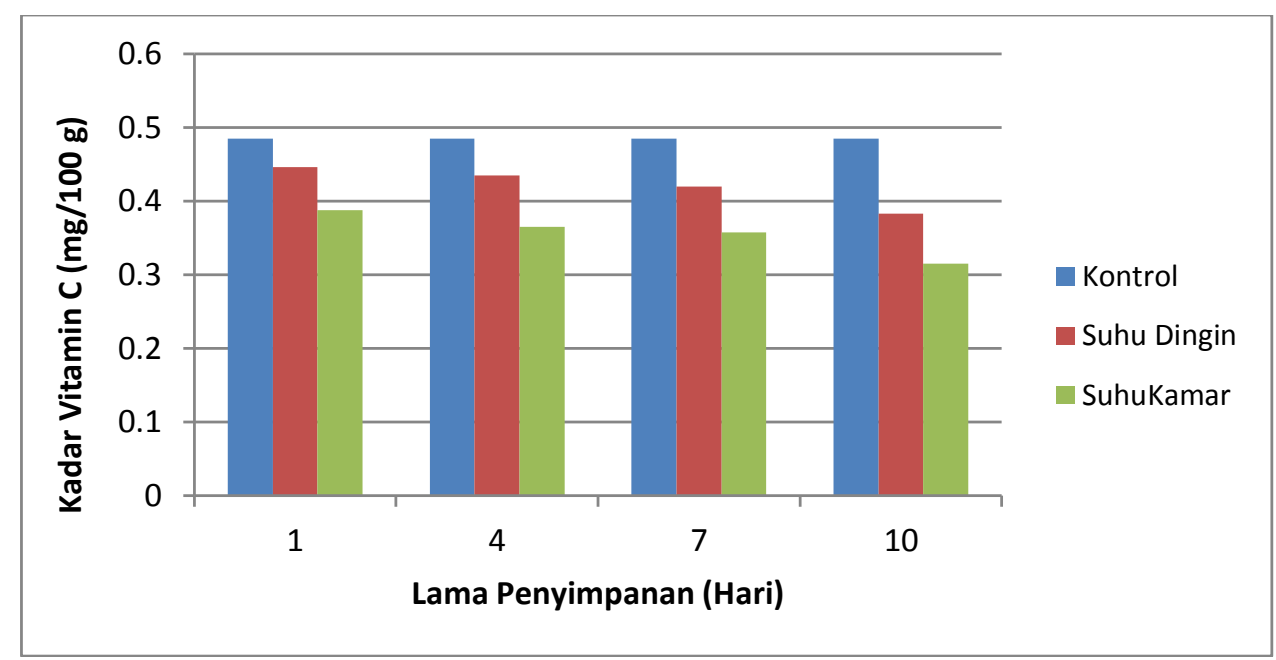

\section{Gambar 2. Pengaruh Suhu dan Lama Penyimpanan Terhadap Kandungan Vitamin C Buah Gandaria.}

Kandungan vitamin $\mathrm{C}$ mengalami penurunan selama penyimpanan dengan suhu dan lama penyimpanan yang berbeda. Sebelum penyimpanan, kandungan vitamin $C$ pada buah gandaria segar sebesar 0,485 $\mathrm{mg} / 100 \mathrm{~g}$ dan setelah penyimpanan pada suhu kamar selama 1, 4, 7 dan 10 hari mengalami penuruan berturut-turut menjadi $0,388 \mathrm{mg} / 100 \mathrm{~g}, 0,365 \mathrm{mg} / 100 \mathrm{~g}, 0,357$ $\mathrm{mg} / 100 \mathrm{~g}$ dan $0,315 \mathrm{mg} / 100 \mathrm{~g}$. Hasil yang sama juga terlihat pada penyimpanan suhu dingin selama 1, 4, 7, dan 10 hari mengalami penurunan berturut-turut menjadi 0,446 $\mathrm{mg} / 100 \mathrm{~g}, 0,435 \mathrm{mg} / 100 \mathrm{~g}, 0,420 \mathrm{mg} / 100 \mathrm{~g}$ dan $0,383 \mathrm{mg} / 100 \mathrm{~g}$.
Kandungan vitamin $\mathrm{C}$ pada buah gandaria yang disimpan pada suhu kamar selama 10 hari mengalami penurunan $35 \%$, sedangkan pada suhu dingin hanya $21 \%$. Hasil uji Anova dari vitamin C menunjukkan bahwa suhu dan lama penyimpanan sangat berpengaruh terhadap kandungan vitamin $\mathrm{C}$ buah gandaria, sedangkan interaksi kedua perlakuan tersebut tidak berpengaruh nyata terhadap kandungan vitamin $\mathrm{C}$ buah gandaria dan selanjutnya, dilakukan uji Duncan. Hasil uji Duncan suhu dan lama penyimpanan terhadap kandungan vitamin C gandaria dapat dilihat pada Tabel 4 di bawah ini. 
Tabel 4. Hasil Uji Duncan Suhu dan Lama Penyimpanan terhadap kandungan vitamin C buah Gandaria

\begin{tabular}{ccc}
\hline Suhu $\left({ }^{\circ} \mathrm{C}\right)$ & Rerata & Notasi \\
\hline Dingin $\left(12-16^{\circ} \mathrm{C}\right)$ & 0.356 & $\mathrm{a}$ \\
Kamar $\left(28-32^{\circ} \mathrm{C}\right)$ & 0.434 & $\mathrm{~b}$ \\
\hline & & \multicolumn{2}{c}{ Notasi } \\
\hline Lama Penyimpanan & Rerata & \multicolumn{2}{c}{$\mathrm{a}$} \\
(hari) & 0.3493 & \multicolumn{2}{c}{$\mathrm{b}$} \\
\hline 10 & 0.3887 & \multicolumn{2}{c}{$\mathrm{bc}$} \\
4 & 0.4000 & \multicolumn{2}{c}{$\mathrm{C}$} \\
1 & 0.4170 & \multicolumn{2}{c}{$\mathrm{d}$}
\end{tabular}

Keterangan: Angka-angka yang diikuti oleh notasi yang tidak sama menunjukkan perbedaan yang nyata.

Hasil uji Duncan Vitamin C buah gandaria untuk perlakuan suhu menunjukkan bahwa perlakuan penyimpanan pada suhu dingin berbeda nyata dengan perlakuan penyimpanan pada suhu kamar.

Hasil uji Duncan Vitamin C buah gandaria untuk perlakuan lama penyimpanan (Tabel 4) menunjukkan bahwa, tanpa penyimpanan ( 0 hari/kontrol) berbeda nyata dengan lama penyimpanan 1 hari, 4 hari, 7 hari, dan 10 hari. Lama penyimpanan 1 hari tidak berbeda nyata dengan lama penyimpanan 4 hari. Selanjutnya, lama penyimpanan 4 hari juga tidak berbeda nyata dengan lama penyimpanan 7 hari, sedangkan lama penyimpanan 10 hari berbeda nyata dengan kontrol dan lama penyimpanan lainnya (1 hari, 4 hari, 7 hari, dan 10 hari).

\section{Pembahasan}

Dari hasil penelitian terlihat bahwa kandungan Vitamin A tertinggi pada buah gandaria terdapat pada kontrol (tanpa penyimpanan) yaitu $0,332 \mathrm{mg} / 100 \mathrm{~g}$ dibandingkan dengan perlakuan suhu dan lama penyimpanan lainnya. Kandungan Vitamin A terendah terdapat pada perlakuan suhu kamar dengan lama penyimpanan 10 hari yaitu $0,260 \mathrm{mg} / 100 \mathrm{~g}$. Kandungan vitamin A yang disimpan pada suhu kamar selama 10 hari mengalami penurunan $21,69 \%$, dan pada suhu dingin hanya $15,36 \%$. Berdasarkan hasil analisis Anova, suhu dan lama penyimpanan sangat berpengaruh terhadap kandungan vitamin $\mathrm{A}$ buah gandaria.
Semakin tinggi suhu, semakin besar penurunan kandungan vitamin A oleh karena terdegradasi oleh panas sensibel kenaikan suhu (Hook, 2007). Vitamin A mudah rusak oleh karena kenaikan suhu dan sinar di sekelilingnya. Vitamin A yang terkandung dalam suatu bahan makanan tidak bisa diujikan, sehingga pada umumnya dalam sebuah penelitian yang diteliti adalah provitamin A yaitu $\beta$-karoten (Almatsier dalam Azeliya, 2013). $\beta$-karoten adalah provitamin $A$ yang diubah oleh tubuh menjadi vitamin A (Eldahshan, 2013). Penurunan kadar $\beta$-karoten dari penyimpanan buah gandaria ini disebabkan oleh sifat dari $\beta$ karoten yang mudah teroksidasi ketika terkena udara, hal ini disebabkan karena adanya 11 ikatan rangkap dua yang terkonjugasi, selain itu $\beta$-karoten juga sangat tidak stabil jika terkena cahaya dan panas sehingga dapat mengalami perubahan isometrik menjadi bentuk cis $\beta$-karoten yang lebih tidak stabil (Hock-Eng dkk. dalam Tungriani dkk., 2012). Senyawa- senyawa karotenoid (termasuk $\beta$-karoten) mempunyai sifat sensitif terhadap alkali, dan sangat sensitif terhadap udara dan sinar terutama pada suhu tinggi. Degradasi $\beta$-karoten akan menghasilkan epoxy karotenoid, apokarotenal, serta senyawa - senyawa volatil (Puspasari, 2009).

Bonnie dan Choo (1999) dikutip dalam Kurniawan (2012), menjelaskan penurunan karatenoid tersebut berkaitan erat dengan tingkat ketidakjenuhan karatenoid yang sangat tinggi, sehingga sangat mudah terdegradasi akibat oksidasi dan suhu yang tinggi. Penggunaan suhu yang lebih rendah 
dapat mempertahankan kandungan $\beta$ karoten dibandingkan penggunaan suhu yang lebih tinggi. Hal ini disebabkan karena reaksi oksidasi karotenoid dapat berjalan lebih cepat pada suhu yang relatif tinggi. Semakin tinggi suhu maka semakin banyak degradasi karoten yang terjadi (Anggara dkk, 2015).

Lama penyimpanan

sangat berpengaruh terhadap vitamin A gandaria. Hal ini karena gandaria memiliki kulit yang tipis yang akan mudah mengalami kerusakan dan pembusukan jika disimpan dalam waktu yang lama. Kerusakan gandaria dapat menyebabkan turunnya gizi yang terkandung di dalamnya termasuk vitamin A (Masfufatun dkk, 2009).

Dari hasil penelitian terlihat bahwa kandungan vitamin $\mathrm{C}$ tertinggi pada buah gandaria terdapat pada kontrol yaitu 0,485 $\mathrm{mg} / 100 \mathrm{~g}$ dibandingkan dengan perlakuan suhu dan lama penyimpanan lainnya. Kandungan Vitamin $\mathrm{C}$ terendah terdapat pada perlakuan suhu kamar dengan lama penyimpanan 10 hari yaitu $0,315 \mathrm{mg} / 100 \mathrm{~g}$. Pada penyimpanan suhu kamar selama 10 hari, kandungan vitamin $\mathrm{C}$ buah gandaria mengalami penurunan $35,05 \%$, sedangkan pada suhu dingin hanya $21,03 \%$.

Penurunan ini disebabkan karena vitamin C merupakan jenis vitamin yang mudah teroksidasi karena senyawanya mengandung gugus fungsi hidroksi $(\mathrm{OH})$ yang sangat reaktif. Udara yang mengandung oksigen dan sinar matahari yang mengandung sinar ultraviolet akan masuk ke dalam buah-buahan sehingga terjadi proses oksidasi. Vitamin $\mathrm{C}$ bersifat tidak stabil, mudah teroksidasi jika terkena udara (oksigen) dan proses ini dapat dipercepat oleh panas. El-Ishaq (2015) mengungkapkan bahwa, vitamin C mudah rusak ketika dimasak dan diolah serta terkena udara dan cahaya. Selain itu, penurunan kandungan vitamin $\mathrm{C}$ juga disebabkan aktivitas asam askorbat oksidase pada saat penyimpanan yang akan merombak asam askorbat di dalam buah. Dimana terjadinya proses respirasi dan oksidasi vitamin $\mathrm{C}$ menjadi asam Ldehidroaskorbat dan mengalami perubahan lebih lanjut menjadi asam L-diketogulonat yang tidak memiliki keaktifan vitamin C sehingga vitamin $\mathrm{C}$ mengalami kerusakan (Winarno dalam Rachmawati, 2009).
Berdasarkan hasil penelitian dapat dilihat bahwa penurunan vitamin $\mathrm{C}$ pada suhu dingin lebih lambat dibanding penyimpanan pada suhu kamar. Hal ini dikarenakan, penyimpanan pada suhu rendah dapat menghambat aktivitas enzim dan reaksi-reaksi kimia serta menghambat atau menghentikan pertumbuhan mikroba (Juniasih dalam Rachmawati, 2009). Gowda, Huddar, Mizrach et al., Rathore et al., dan Srinivasa et al., (2002) yang dikutip dalam Baloch (2012), menjelaskan proses metabolisme, proses kimia dan prosee biologi buah akan bertambah seiring dengan meningkatnya suhu penyimpanan. Pada keadaan penyimpanan rendah, aktivitas metabolism menjadi rendah sehingga laju respirasinya menjadi turun yang dapat mengahambat penurunan kadar vitamin $\mathrm{C}$. Hal ini juga didukung oleh Trenggono dan Sutardi (1989) dikutip dalam Rachmawati (2009), yang menyatakan bahwa tujuan penyimpanan suhu rendah adalah untuk mencegah kerusakan tanpa mengakibatkan perubahan yang tidak diinginkan seperti terjadinya pembusukan. Dengan pendinginan dapat memperlambat kecepatan reaksi-reaksi metabolisme. Oleh karena itu, dengan penyimpanan pada suhu rendah dapat memperpanjang masa hidup dari jaringan-jaringan di dalam bahan pangan tersebut. Hal ini tidak hanya disebabkan proses respirasi yang menurun, tetapi juga karena terhambatnya pertumbuhan mikroba penyebab kebusukan dan kerusakan (Winarno dalam Rachmawati, 2009).

Disamping itu, lama penyimpanan sangat berpengaruh terhadap vitamin C pada buah gandaria. Hal ini karena gandaria memiliki kulit yang tipis yang akan mudah mengalami kerusakan dan pembusukan jika disimpan dalam waktu yang lama. Kerusakan gandaria dapat menyebabkan turunnya gizi yang terkandung di dalamnya termasuk vitamin C (Masfufatun dkk, 2009).

\section{KESIMPULAN DAN SARAN Kesimpulan}

Dari hasil penelitian dapat disimpulkan sebagai berikut:

1. Terdapat pengaruh nyata terhadap kandungan vitamin A pada buah gandaria yang disimpan pada suhu 
kamar $\left(28-32^{\circ} \mathrm{C}\right)$ dan suhu dingin (12$\left.16^{\circ} \mathrm{C}\right)$. Suhu dingin dapat menghambat penurunan kandungan vitamin $\mathrm{A}$ dibanding suhu kamar.

2. Lama penyimpanan berpengaruh nyata terhadap kandungan vitamin A buah gandaria. Semakin lama penyimpanan, kandungan vitamin A semakin kecil.

3. Terdapat pengaruh nyata terhadap kandungan vitamin $\mathrm{C}$ pada buah gandaria yang disimpan pada suhu kamar $\left(28-32^{\circ} \mathrm{C}\right)$ dan pada suhu dingin $\left(12-16^{\circ} \mathrm{C}\right)$. Suhu kamar dapat mempercepat penurunan kandungan vitamin $\mathrm{C}$ buah gandaria dibanding suhu dingin.

4. Lama penyimpanan berpengaruh nyata terhadap kandungan vitamin C buah gandaria. Semakin lama penyimpanan maka kandungan vitamin $C$ semakin kecil.

\section{Saran}

1. Buah gandaria sebaiknya dikonsumsi dalam keadaan segar. Apabila tidak segera dikonsumsi sebaiknya disimpan $\leq 7$ hari pada suhu kamar atau $\leq 10$ hari pada suhu lemari es.

2. Untuk asupan vitamin A, buah gandaria sebaiknya dimakan dalam kondisi segar (dipetik langsung dikonsumsi) dan setelah disimpan pada suhu dingin selama 4 hari

3. Untuk asupan vitamin $\mathrm{C}$, buah gandaria sebaiknya dimakan dalam kondisi segar.

4. Bagi mahasiswa, disarankan untuk melakukan penelitian kandungan vitamin $A$ dan $C$ pada buah gandaria yang disimpan pada suhu $<12^{\circ} \mathrm{C}$.

\section{DAFTAR PUSTAKA}

Anggara P. T., E. Zubaidah, I \& Purwantiningrum. 2015. Pengaruh Edible Coating Sebagai Barrier Oksigen pada Pembuatan Wortel Instan. Jurnal Pangan dan Agroindustri, 3 (4): 17221729

Azeliya, R. M. 2013. Pembuatan Bolu Brokoli (Brassica Oleracea L) Dilihat Dari Kadar B- Karoten Dan Kadar Vitamin C Serta Daya Terima. Karya Tulis Ilmiah. Naskah Publikasi. Fakultas IImu
Kesehatan. Universitas Muhammadiyah Surakarta.

Bakhtiar, M. 2008. Pengaruh Cara dan Lama Penyimpanan Dingin Terhadap Kandungan Vitamin $C$ dan Aktivitas Antioksidan Cabai Merah. Skripsi. Jurusan Biologi, Fakultas Sains Teknologi, UIN Malang (online), (http://etheses.uinmalang.ac.id/1011/1/04520030\%20Skri psi.pdf), diakses 14 Januari 2016

Baloch, M. K. 2012. Effect of Harvesting and Storage conditions on The Post Harvest Quality and Shelf Life of Mango (Mangifera indica L.) Fruit. South African Journal of Botany. Department of Chemistry. Gomal University, Dera Ismail Khan, Pakistan.

Eldahshan, A. O. \& Singab, A. N. B. 2013. Caratenoids. Journal of Pharmacognosy and Phytochemistry. Faculty of Pharmacy, Ain Shams University, Cairo, Egypt.

El-Ishaq, A. \& Obirinakem, S. 2015. Effect of Temperature and Storage on Vitamin C Content in Fruits Juice. International Journal of Chemical and Biomolecular Science. Chemistry/Biochemistry Unit, Federal Polytechnic, Damaturu Nigeria, 1(2): 17-21

Hook, T. K., Setyo, W., Irawaty, W. \& Sotaredjo, F. E. 2007. Pengaruh Suhu Dan Waktu Pemanasan Terhadap Kandungan Vitamin A Dan C Pada Proses Pembuatan Pasta Tomat. Jurusan Teknik Kimia. Universitas Katolik Widya Mandala Surabaya, 6 (2): 111-120

Kurniawan, C. 2012. Kajian Penurunan Beta Karoten Selama Pembuatan Flakes Ubi Jalar (Ipomoea batatas Lam) Dalam Berbagai Suhu Pemanggangan (online), (https://id.scribd.com/doc/87606308/Kaj ian-Penurunan-Beta-Karoten-SelamaPembuatan-Flakes-Ubi-Jalar), diakses 17 Maret 2016

Mailoa, M. 2012. Pengaruh Natrium Benzoat Dan Lama Penyimpanan Terhadap Mutu Selai Gandaria. Jurnal Ekologi dan Sains. Fakultas Pertanian Universitas Pattimura Ambon

Masfufatun, Widaningsih, Kumala, N. \& Rahayuningsih, T. 2009. Pengaruh Suhu dan Waktu Penyimpanan Terhadap Vitamin C Dalam Jambu Biji 
(Psidium guajava). Universitas Wijaya Kusuma, Surabaya.

Parwata, O.A., Ratnayani, K. \& Listya, A. 2010. Aktivitas Antiradikal Bebas Serta Kadar Beta Karoten pada Madu Randu dan Madu Kelengkeng. Jurnal Kimia. FMIPA Universitas Udayana Bukit Jimbaran, 4 (1): 54-62

Puspasari, D. P. W. 2009. Pengaruh Penutupan dan Suhu pada Proses Perebusan Terhadap Karakteristik Sirup Wortel. Jurnal Agroteknologi. Jurusan IImu dan Teknologi Pangan Fakultas
Teknologi Pertanian Universitas Udayana.

Rachmawati, Defiani, R. M. R. \& Suriani, N. L. 2009. Pengaruh Suhu dan Lama Penyimpanan Terhadap Kandungan Vitamin C pada Cabai Rawit Putih. Jurnal Biologi. Fakultas MIPA Univeritas Udayana, 13 (2): 36-40

Tungriani, D. A. 2012. Analisis Kandungan B-Karoten Dan Vitamin C Pada Berbagai Varietas Talas (Colocasia esculenta) Indonesia. Skripsi. Jurusan Kimia, FMIPA, Universitas Hasanuddin Makassar. 